\title{
Studies on Cystic Fibrosis Using Isoelectric Focusing. I. An Assay for Detection of Cystic Fibrosis Homozygotes and Heterozygote Carriers from Serum
}

\author{
GREGORY B. WILSON, (45) AND H. HUGH FUDENBERG \\ Section of Immunology, Department of Medicine, University of California, San Francisco. California. USA
}

THEODORE L. JAHN

Department of Biology. University of California, Los Angeles, California, USA

\section{Extract}

We have developed a standardized biophysical assay for the rapid detection of individuals homozygous or heterozygous for cystic fibrosis $(C / F)$. The assay employs isoelectric focusing in thin layer polyacrylamide gels to analyze microliter quantities of whole serum for the presence of a $\mathrm{C} / \mathrm{F}$ factor protein and for deletions in a group of proteins called proteins $\mathrm{B}, \mathrm{C}$, and $\mathrm{D}$ (Fig. 1). A pH 5-10 gradient is used (Fig. 2) and each sample is screened using a serum volume which contains $300 \mu \mathrm{g}$ immunoglobulin G (IgG). Individuals homozygous or heterozygous for $C / F$ are distinguished from normal unaffected individuals on the basis of the presence of a $C / F$ factor protein band (Table 1). Heterozygous carriers for $C / F$ are distinguished from $\mathrm{C} / \mathrm{F}$ homozygotes $75 \%$ of the time, on the basis of a deletion in either band $B, C$, or D (Table 2 ).

On the basis of screening 65 patients with cystic fibrosis. 61 heterozygous carriers for $C / F$, and 105 normal control subjects, it was concluded that no obvious correlation existed between either sex, age, or severity of the disease in the individual $\mathrm{C} / \mathrm{F}$ patient, and the absolute presence or absence of the $\mathrm{C} / \mathrm{F}$ factor. In addition, no correlation existed between sex or age and the presence of the $C / F$ factor or deletions in proteins $B, C$, and $D$ in the individual heterozygous carrier for $C / F$ or normal control subjects. Analysis of serum samples from 68 patients with a variety of other diseases, many with clinical symptoms resembling those seen in the patient with cystic fibrosis ( $T$ able 3 ), indicated that the $\mathrm{C} / \mathrm{F}$ factor protein described in this study appears to be diagnostic for $C / F$ genotypes, with the possible exception of patients with certain types of leukemia.

\section{Speculation}

The biophysical assay described in this report or a modification of it may prove to be a useful method for the routine detection of carriers of cystic fibrosis in the general population.

Cystic fibrosis is a generalized metabolic disorder for which the primary genetic defect is unknown. The classic features of this autosomal recessive disorder include chronic pulmonary disease. pancreatic deficiency with steatorrhea and azotorrhea, and elevated concentrations of electrolytes in the sweat (24).

In 1967, Spock et al. (29) first described the presence of a protein factor (ciliary dyskinesiary factor, $\mathrm{C} / \mathrm{F}$ factor) which was apparently uniquely found in the serum of $\mathrm{C} / \mathrm{F}$ patients (homozygotes for cystic fibrosis) and heterozygote carriers of the disease. The presence of this factor was detected by its ability to cause dyskinesia in the normal beating pattern of ciliated preparations from rabbit trachea (29). Since that time, other bioassays for $C / F$ factor have been described. These include the oyster gill ciliary assay developed by Bowman et al. (8), an assay utilizing the fresh water mussel developed by Besley et al. (4), and a recent modification of the original rabbit tracheal assay (29) described by Conover et al. (13).

Although each of these bioassays appears to be capable of detecting a $\mathrm{C} / \mathrm{F}$ factor in serum from most $\mathrm{C} / \mathrm{F}$ patients and heterozygous carriers of cystic fibrosis, they are currently not practical assays for screening programs to detect heterozygotes or for the routine clinical diagnosis of this disease $(5,24)$. Each assay is time consuming, moderately expensive, and requires a trained observer (24). In addition, their widespread use is limited by seasonal and regional inaccessibility of the ciliated tissue $(4,9)$, by the requirement for organ culture $(13,17,24)$, and by difficulties in quantitation of target cell numbers (e.g.. they are not standardized) $(4,9,13,29)$. Furthermore, the assays do not distinguish between an individual homozygous and one heterozygous for cystic fibrosis $(4,5,9,24,29)$.

In a previous report (35), we showed that by using isoelectric focusing in thin layer polyacrylamide gels, a $\mathrm{C} / \mathrm{F}$ factor-like protein could be detected in whole serum samples from both $C / F$ patients and heterozygote carriers of cystic fibrosis, but was not found in most normal control samples. This cationic protein, which has a pI (isoelectric point) of 8.41 when disassociated from IgG in $4 \mathrm{M}$ urea and a molecular weight between $1,000-10,000$ ( 32 , 33,35 ), displays physical-chemical properties similar to those found for the $\mathrm{C} / \mathrm{F}$ factor by other investigators $(13,7,9,16,17$, 24-26).

We have now extended our initial findings $(32,35)$ and have developed a standardized biophysical assay for the rapid detection of individuals homozygous and heterozygous for $\mathrm{C} / \mathrm{F}$. The purpose of the present report is threefold: (l) to present the detailed methodology of the assay, (2) to present the results of an analysis of a large number of $\mathrm{C} / \mathrm{F}$ patients (varying greatly with respect to age and severity of the disease), heterozygote carriers of $C / F$, and normal control subjects, and (3) to present the findings on the specificity of this assay for cystic fibrosis as judged by an analysis of samples from other patients having a variety of diseases, many with clinical features similar to those seen in the C/F patient (29).

\section{MATERIALS AND METHODS}

\section{COLLECTION AND PROCESSING OF SAMPLES}

Sixty-five clinically ascertained $\mathrm{C} / \mathrm{F}$ patients and 61 of their parents (heterozygote carriers of cystic fibrosis) were chosen for this study from individuals who attended a Cystic Fibrosis Clinic located at either the Department of Pediatrics, University of 
California, Los Angeles: San Bernardino County General Hospital; Department of Pediatrics, University of California, San Francisco; or Children`s Hospital at Stanford. The diagnosis was confirmed in all patients by the clinical history and the presence of an elevated concentration of chloride in the sweat $(20)$. The $\mathrm{C} / \mathrm{F}$ patients had Schwachman scores (27) which ranged from 20 to 90 , and ages which ranged from 1 to 34 years. Twenty-eight of the patients were mate and 37 were female. Forty-nine of the heterozygous carriers of cystic fibrosis were female and 12 were male. The ages of the heterozygous carriers ranged from 20 to 56 years.

One hundred five individuals (normal control subjects) were also studied who had no known family history or clinical history indicative of cystic fibrosis and who were clinically healthy. There were 55 female and 50 male normal control subjects whose ages ranged from 7 to 64.5 years. In addition, 68 individuals were studied who had a disease other than cystic fibrosis (normal patient control subjects) and no known family history or clinical history indicative of cystic fibrosis (see Analysis of Sera from Individuals with Other Disease States under Results for disease states included and ages of the subjects).

Venous blood was collected from each individual used in this study after obtaining informed consent, and allowed to clot in glass tubes at $4^{\circ}$ for $4.6 \mathrm{hr}$. The samples were then centrifuged at 1,700 $\times g$ for $10 \mathrm{~min}$ at $4^{\circ}$ and the serum transferred to plastic tubes and frozen in aliquots at $-70^{\circ}$.

All samples were analyzed by electrofocusing within $1-10$ days after collection. Serum samples which are hemolyzed, frozen and thawed more than once, obtained from blood samples left at room temperature for greater than $2 \mathrm{hr}$, at $4^{\circ}$ for greater than $24 \mathrm{hr}$, or obtained from heparinized or citrated biood are unsuitable and should not be used, as these samples will invariably have decreased amounts of $\mathrm{C} / \mathrm{F}$ factor as compared with analogous samples processed at $4^{\circ}$ from clotted blood (31).

\section{QUANTITATION OF IgG}

The concentration of $\operatorname{IgG}$ in each serum sample was determined by single radial immunodiffusion using the methods of Fahey and McKelvey (19) or Mancini et al. (22).

\section{ISOELECTRIC FOCUSING}

Isoelectric focusing in thin layer polyacrylamide gels was performed in principle as described previously $(30,35)$. In this study only gradients of $\mathrm{pH} \mathrm{5-10} \mathrm{were} \mathrm{used.} \mathrm{The} \mathrm{following} \mathrm{mixture}$ was usually employed: $1.2 \mathrm{ml}, \mathrm{pH} 5-8 ; 0.8 \mathrm{ml}, \mathrm{pH} 8-9.5 ; 0.2 \mathrm{ml}$, pH 7-9; and 0.2 ml, pH 9-11 Ampholine carrier ampholytes (36), were mixed with $31.2 \mathrm{ml}$ of a $5.13 \mathrm{M}$ urea solution. To this solution, $6.0 \mathrm{ml}$ stock solution of acrylamide $(33.0 \mathrm{~g} / 100 \mathrm{ml})$ and bisacrylamide $(1.0 \mathrm{~g} / 100 \mathrm{ml})(37)$ and $0.2 \mathrm{ml}$ of a stock solution of $5 \%(w / v)$ TEMED were added (38). After deaeration under reduced pressure for $1-2 \mathrm{~min}$ with mild agitation, $0.2 \mathrm{ml}$ of $10 \%$ ammonium persulfate solution was added to induce polymerization. All solutions were made up with double-distilled deionized water. This mixture results in a gel with $\mathrm{T}=5 \%$ and $\mathrm{C}=3 \%$ (39), containing $2.3 \%(\mathrm{w} / \mathrm{v})$ Ampholine carrier ampholytes and $4 \mathrm{M}$ urea.

The gels were prefocused for $1 \mathrm{hr}$ at $6 \mathrm{ma}$ (constant current)/gel to remove residual ammonium persulfate. After prefocusing, samples were pipetted onto $10-\mathrm{mm}$ wide pads of Whatman no. $3 \mathrm{MM}$ chromatography paper, which were placed on the gel in a line parallel to the anode and at a distance of approximately $1.5 \mathrm{~cm}$ from the anodic end of the gel (30). Electrofocusing was performed at $4^{\circ}$ for $18 \mathrm{hr}$ at $500 \mathrm{~V}$ (constant voltage) then for $3 \mathrm{hr}$ at $1.000 \mathrm{~V}$. The $\mathrm{pH}$ gradient was then recorded at $4^{\circ}(35)$. The gels were then fixed overnight at $4^{\circ}$ in a solution of $12 \%(\mathrm{w} / \mathrm{v})$ trichloracetic acid, $5 \%(\mathrm{w} / \mathrm{v})$ sulfosalicylic acid, in ethanol-water-acetic acid $(6: 13: 1$, by volume) with gentle rocking. They were stained subsequently with Coomassie brilliant blue $(0.1 \% \mathrm{w} / \mathrm{v}$, in ethanol-water-acetic acid, 9:9:2, by volume) and destained rapidly in ethanol-wateracetic acid $(6: 13: 1$, by volume) at room temperature $(30,35)$.

\section{ASSAY FOR CYSTIC FIBROSIS FACTOR AND OTHER PROTEIN BANDS}

Ten serum samples per gel are subjected to electrofocusing using a pH 5-10 gradient as described above. To facilitate simultaneous screening of a large number of samples, multiple gels can be run under identical conditions from the same power supply by setting up isoelectric focusing units in parallel (35).

Each sample was analyzed by electrofocusing in a $\mathrm{pH} 5.10$ gradient, using a volume of serum which contained $300 \mu \mathrm{g} \mathrm{IgG}$ (40). In preliminary studies, we had found that the volume of serum necessary to demonstrate the presence of a $\mathrm{C} / \mathrm{F}$ factor protein band in the sera of $\mathrm{C} / \mathrm{F}$ patients and heterozygote carriers was extremely variable $(32,35)$. To standardize the volume of serum used for the analysis, it was decided to use the level of $\operatorname{lgG}$ in each sample, for ample evidence exists suggesting either that IgG may serve as a carrier of $\mathrm{C} / \mathrm{F}$ factor in serum, or that the $\mathrm{C} / \mathrm{F}$ factor binds or complexes noncovalently to $\operatorname{IgG}(1,3,5,7-9,16$, $17,25,32,34,35)$. Therefore, on the assumption that a stoichiometric relationship existed between the quantity of $\mathrm{C} / \mathrm{F}$ factor and $\mathrm{IgG}$, an amount of $\operatorname{lgG}(300 \mu \mathrm{g})$ was established which when used, would: (l) allow the detection of the $\mathrm{C} / \mathrm{F}$ factor in all serum samples from persons homozygous or heterozygous for the $\mathrm{C} / \mathrm{F}$ gene, and (2) would not necessitate using volumes of serum exceeding $100 \mu \mathrm{l}$. A volume of serum exceeding $100 \mu \mathrm{l}$ was found to cause distortions in the protein banding pattern obtained, apparently because of the high concentrations of electrolytes and proteins (i.e., albumin) found in serum.

One normal control sample and one cystic fibrosis homozygote or heterozygote carrier sample are included per gel to facilitate subsequent screening of samples of known or unknown identity for the proteins described in this and other reports $(32,33,35)$. After being destained, the gels are air dried for $1 \mathrm{hr}$, placed on an $\mathrm{x}$-ray view box, and visually examined with the aid of an orange filter (41). The presence or absence of cystic fibrosis factor $(32,33,35)$ and other protein bands in each sample is determined by comparison of their protein banding patterns to that of the controls. When necessary, the location of a protein band can be quantified by determining its $\mathrm{pI}$ and distance (in millimeters) from the anode or a suitable marker protein (i.e... albumin) by direct measurement after placing the gel over a sheet of millimeter-ruled graph paper (see Results).

\section{RESULTS}

\section{ANALYSIS OF SERA FROM C/F PATIENTS, HETEROZYGOTE CAR-} RIERS FOR C/F AND NORMAL CONTROL SUBIECTS

The results of screening for the presence of cystic fibrosis factor in sera from $C / F$ patients, heterozygote carriers for $C / F$, and normal control subjects are presented in Table 1 . As shown, a sample volume containing $300 \mu \mathrm{g} \mathrm{IgG} \mathrm{appears} \mathrm{to} \mathrm{be} \mathrm{optimal} \mathrm{for}$ the assay. The $\mathrm{C} / \mathrm{F}$ factor protein band was found in 63 of $65 \mathrm{C} / \mathrm{F}$ patients $(59+, 4 \pm)$ and 57 of 61 heterozygote carriers $(50+, 7 \pm)$; in contrast, only $9(7+, 2 \pm)$ samples from 105 normal control subjects showed a $\mathrm{C} / \mathrm{F}$ factor protein band. The nine normal control subjects positive for the $\mathrm{C} / \mathrm{F}$ factor were all adults. The sample volumes needed for the analysis ranged from 10 to $70 \mu 1,15$ to $90 \mu \mathrm{l}$, and 15 to $85 \mu \mathrm{l}$ for $\mathrm{C} / \mathrm{F}$, heterozygote, and normal control samples, respectively.

To ascertain whether samples negative for $C / F$ factor on an analysis of a volume of serum containing $300 \mu \mathrm{g} \mathrm{IgG} \mathrm{might} \mathrm{be}$ positive when a larger volume of serum was used, all negative $C / F$ and heterozygote samples and 50 of 96 normal control samples were analyzed using a volume of serum containing $400 \mu \mathrm{g} \mathrm{IgG.} \mathrm{A}$ $\mathrm{C} / \mathrm{F}$ factor band could be demonstrated in none of these samples. No direct correlation was noted between age or severity of the 
Table 1. Presence of cystic fibrosis factor in cystic fibrosis homozlgote, heterozlgote carrier, and normal control samples when volume of serum analyzed is based on $\operatorname{Ig} G$ level

\begin{tabular}{|c|c|c|c|c|c|c|}
\hline \multirow{2}{*}{$\begin{array}{l}\text { Type of serum } \\
\text { tested }\end{array}$} & \multirow{2}{*}{$\begin{array}{l}\text { IgG level } \\
\mathrm{mg} / 100 \mathrm{ml}\end{array}$} & \multirow{2}{*}{$\begin{array}{c}\text { Volume } \\
\text { of sample } \\
\text { containing } \\
300 \mu \mathrm{g} \\
\operatorname{IgG}(\mu \mathrm{l})\end{array}$} & \multirow{2}{*}{$\begin{array}{l}\text { Age of } \\
\text { individ- } \\
\text { ual, yr }\end{array}$} & \multicolumn{3}{|c|}{$\begin{array}{c}\text { Cystic fibro- } \\
\text { sis factor } \\
\text { present }^{3}\end{array}$} \\
\hline & & & & + & \pm & - \\
\hline $\begin{array}{l}\text { Cystic fibrosis } \\
\text { homozygote } \\
(65)\end{array}$ & $\begin{array}{l}1,431 \pm 662^{1} \\
430-3,800^{2}\end{array}$ & $\begin{array}{l}25 \pm 15 \\
10-70\end{array}$ & $\begin{array}{c}13.3 \pm 7.4 \\
1.0-34.0\end{array}$ & 59 & 4 & 2 \\
\hline $\begin{array}{l}\text { Heterozygote car- } \\
\text { rier of cystic } \\
\text { fibrosis }(61)\end{array}$ & $\begin{array}{l}959 \pm 286 \\
333-1,739\end{array}$ & $\begin{array}{l}35 \pm 12 \\
15-90\end{array}$ & $\begin{array}{l}35.1 \pm 10.0 \\
20.0-56.0\end{array}$ & 50 & 7 & 4 \\
\hline $\begin{array}{l}\text { Normal controls } \\
\qquad(105)\end{array}$ & $\begin{array}{l}1,027 \pm 410 \\
358-2,380\end{array}$ & $\begin{array}{l}34 \pm 12 \\
15-85\end{array}$ & $\begin{array}{r}40.4 \pm 13.0 \\
7.0-64.5\end{array}$ & 7 & 2 & 96 \\
\hline
\end{tabular}

${ }^{1}$ Mean \pm SD

${ }^{2}$ Range.

${ }^{3}+$ : cystic fibrosis factor band present; \pm : band present but faint; band not present at level tested.

disease (as judged by Schwachman scores which ranged from 20 to 90) (27) in the individual C/F patient, heterozygous carrier of $\mathrm{C} / \mathrm{F}$, or normal control subject positive for $\mathrm{C} / \mathrm{F}$ factor.

The two $\mathrm{C} / \mathrm{F}$ patients who failed to show a $\mathrm{C} / \mathrm{F}$ factor band were males, aged I year and 34 years, with IgG levels of 530 $\mathrm{mg} / 100 \mathrm{ml}$ and $900 \mathrm{mg} / 100 \mathrm{ml}$ and Schwachman scores of 45 and 75 , respectively. These two $\mathrm{C} / \mathrm{F}$ patients were not related nor were they related to the four heterozygote carriers who were negative for $\mathrm{C} / \mathrm{F}$ factor. Serum samples from both parents of the younger $\mathrm{C} / \mathrm{F}$ factor negative $C / F$ patient were analyzed by electrofocusing and were found to be positive for the $C / F$ factor. Serum samples from the parents of the older $\mathrm{C} / \mathrm{F}$ factor negative $\mathrm{C} / \mathrm{F}$ patient were not obtainable.

A typical result of the protein banding patterns obtained for $\mathrm{C} / \mathrm{F}$, heterozygote carrier, and normal control samples when analyzed by electrofocusing is shown in Figure 1. The $\mathrm{pH}$ gradient as estimated with a surface $\mathrm{pH}$ electrode at $4^{\circ}$ is shown in Figure 2. Based on the analysis of 129 samples found to contain the $\mathrm{C} / \mathrm{F}$ factor band (Table 1) this protein was found to focus at a distance of $13.3 \pm 0.2 \mathrm{~cm}$ from the anode or about $92 . \pm 0.2 \mathrm{~cm}$ from albumin (Fig. 1). This corresponds to a calculated pl for this protein of about $8.46 \pm 0.05$, which agrees well with a value of 8.41 \pm 0.10 reported previously $(32,35)$.

In addition to the $\mathrm{C} / \mathrm{F}$ factor band, another group of protein bands have been found which appear to be useful in differentiating individuals heterozygous for $\mathrm{C} / \mathrm{F}$ from $\mathrm{C} / \mathrm{F}$ patients and normal control subjects. These protein bands are labeled B. C, and D in Figure 1. They focus between 11.0 and $12.0 \mathrm{~cm}$ from the anode in a pH 5-10 gradient and have calculated pI values between 7.85 and 8.10 (Fig. 2).

Table 2 shows the frequency of deletions in these bands when samples identical with those in Table 1 are examined by electrofocusing using sample volumes containing $300 \mu \mathrm{g} \mathrm{IgG.} \mathrm{Forty-}$ six of 61 heterozygote carriers of $\mathrm{C} / \mathrm{F}$ lacked one of these three bands (13B, 15C, 18D), but 15 of 61 lacked none of these bands. Of the nine normal controls which were found to contain $\mathrm{C} / \mathrm{F}$ factor (Table 1), three lacked band B, two band C, and two band D, whereas two lacked none of these bands. All of the 96 normal controls found to lack $\mathrm{C} / \mathrm{F}$ factor (Table 1) also showed no deletions in these bands. Out of $65 \mathrm{C} / \mathrm{F}$ patient samples studied, 64 showed no deletions in these proteins. The one C/F sample who lacked band B also lacked C/F factor (Table 2). This male patient was 34 years old with a Schwachman score and IgG level of 75 and $900 \mathrm{mg} / 100 \mathrm{ml}$, respectively.

\section{ANALYSIS OF SERA FROM INDIVIDUALS WITH OTHER DISEASE} STATES

Table 3 presents the results of an analysis of sera from individuals with disease states other than cystic fibrosis. Each sample was analyzed by electrofocusing using a serum volume which contained $300 \mu \mathrm{g} \mathrm{IgG}$ for the presence of a $\mathrm{C} / \mathrm{F}$ factor protein band (Fig. 1). Of 69 individuals studied (representing 23 disease states), 9 were positive for a $\mathrm{C} / \mathrm{F}$ factor band. One of these

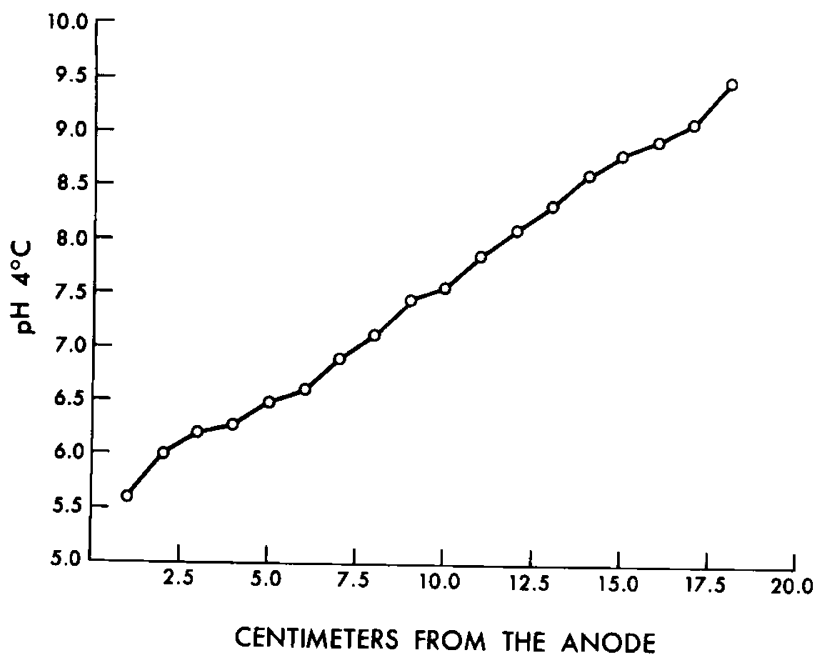

Fig. 1. Results of isoelectric focusing of whole human serum in $5 \%$ polyacrylamide, 2.3\% (w/v) Ampholine carrier ampholytes, pH 5-10, $4 \mathrm{M}$ urea. The protein banding pattern for samples from two normal controls $(N C)$, two heterozygous carriers of cystic fibrosis $(\mathrm{C} / \mathrm{F})(H C F)$, and one $\mathrm{C} / \mathrm{F}$ patient $(C F)$ are shown. All samples contained $300 \mu \mathrm{g}$ IgG. The location of the $\mathrm{C} / \mathrm{F}$ factor protein $(C F F)$ and protein $\mathrm{B}, \mathrm{C}$, and $\mathrm{D}$ are indicated by arrows. The heterozygote carrier sample on the extreme left is missing band D. A centimeter scale (right) shows the distance of each protein band from the anode. The location of albumin $(a l b$.$) is also$ indicated.

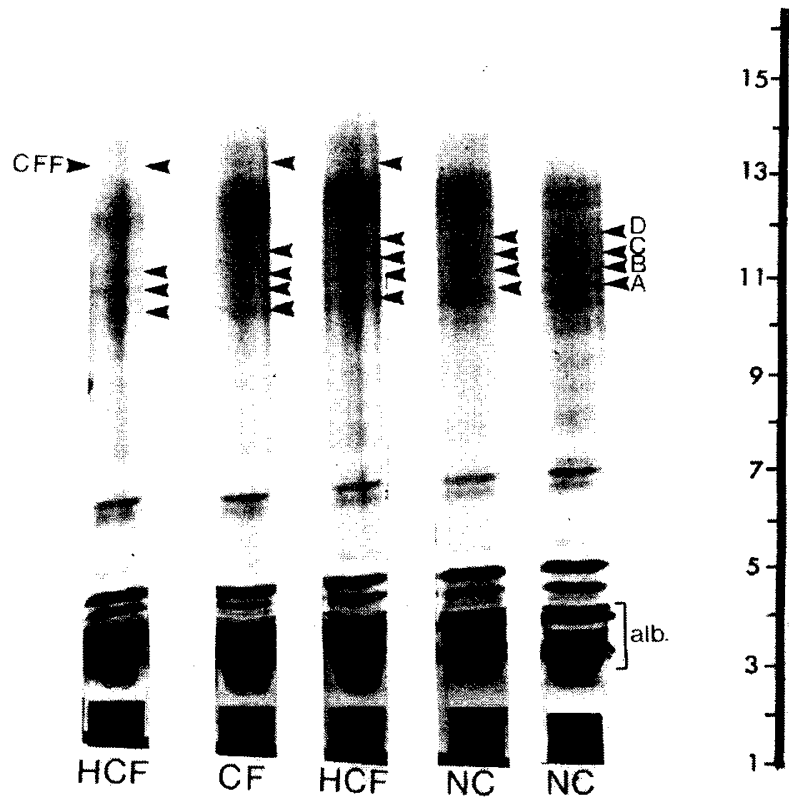

Fig. 2. Result of $\mathrm{pH}$ measurement at $4^{\circ}$ on the surface of a polyacrylamide gel from anode to cathode in an experiment corresponding to Figure 1. 
Table 2. Frequency of deletions in protein bands $B, C$, and $D$ in cvstic fibrosis homozl'gote, heterozvgote carrier, and normal control serum samples; relationship to the presence of cystic fibrosis factor

\begin{tabular}{|c|c|c|c|c|c|c|c|}
\hline \multirow{2}{*}{$\begin{array}{l}\text { Type of serum } \\
\text { tested }\end{array}$} & \multirow[b]{2}{*}{ No. } & \multicolumn{3}{|c|}{ Bands present ${ }^{1}$} & \multicolumn{3}{|c|}{$\begin{array}{l}\text { Cystic fibrosis }{ }^{2} \\
\text { factor present }\end{array}$} \\
\hline & & B & C & D & + & \pm & - \\
\hline \multirow{4}{*}{$\begin{array}{l}\text { Heterozygote carrier of } \\
\text { cystic fibrosis (61) }\end{array}$} & 13 & - & + & + & 10 & 2 & 1 \\
\hline & 15 & + & - & + & 13 & 1 & 1 \\
\hline & 18 & + & + & - & 14 & 3 & 1 \\
\hline & 15 & + & + & + & 13 & 1 & 1 \\
\hline \multirow{2}{*}{$\begin{array}{l}\text { Cystic fibrosis } \\
\text { homozygote (65) }\end{array}$} & 1 & - & + & + & 0 & 0 & 1 \\
\hline & 64 & + & t & + & 59 & 4 & 1 \\
\hline \multirow[t]{4}{*}{ Normal control (105) } & 3 & - & + & + & 2 & 1 & 0 \\
\hline & 2 & + & - & + & 2 & 0 & 0 \\
\hline & 2 & + & + & - & 1 & 1 & 0 \\
\hline & 98 & + & + & + & 2 & 0 & 96 \\
\hline
\end{tabular}

$1+$ : band present; - : band absent.

${ }^{2}+, \pm,-:$ as in Table 1.

was a sibling of a known $\mathrm{C} / \mathrm{F}$ patient, and is therefore at risk for being a heterozygote carrier of $\mathrm{C} / \mathrm{F}$ or for having cystic fibrosis. As his sweat chloride level was found to be within the normal range when tested on three separate occasions, he is presumed to be a heterozygote carrier. This male individual was 4 years of age, had an IgG level of $945 \mathrm{mg} / 100 \mathrm{ml}$, and is one of eight patients with allergy studied (Table 3 ).

Of the nine patients found to have a $\mathrm{C} / \mathrm{F}$ factor band, two showed deletions in bands, B, C, or D; one was the child with chronic allergy $(\mathrm{B}-)$, and the other was the patient with cancer of the bladder $(\mathrm{C}-)$. None of the 60 patients negative for $\mathrm{C} / \mathrm{F}$ factor showed a deletion in bands $\mathrm{B}, \mathrm{C}$, or $\mathrm{D}$. The most interesting finding was that four of five patients with leukemia showed a protein band which focused at a position apparently identical with that of the $\mathrm{C} / \mathrm{F}$ factor. Three of these patients were adults with either acute granulocytic leukemia or chronic monocytic leukemia (all + ). The other two leukemics were both children ( 6 years, 17 years) and had acute lymphocytic leukemia $(1 \pm, 1-)$.

\section{DISCUSSION}

The present communication stems from the finding that a $\mathrm{C} / \mathrm{F}$ factor-like protein could be demonstrated by isoelectric focusing in thin layer polyacrylamide gels, both in whole serum and the IgG fraction thereof of individuals homozygous or heterozygous for the cystic fibrosis gene $(32,33,35)$. This finding and the suggestion derived from experimental results that there may be a stoichiometric relationship between the quantity of this $\mathrm{C} / \mathrm{F}$ factor and $\operatorname{IgG}(5$, $7 \ldots 9,11,16,17,25,32,34,35)$ has been utilized to develop a standardized biophysical assay for $\mathrm{C} / \mathrm{F}$ factor detection in sera from both homozygotes and heterozygotes for cystic fibrosis. Although the relationship of this $\mathrm{C} / \mathrm{F}$ factor to the pathophysiology of cystic fibrosis remains to be elucidated, its presence in asymptomatic heterozygote carriers suggests that it may be directly or indirectly related to the primary genetic defect in cystic fibrosis.

In addition to the $\mathrm{C} / \mathrm{F}$ factor protein, another group of protein bands have been described (bands B, C, and D) which appear to be useful in distinguishing between heterozygote carriers for $C / F$ and $\mathrm{C} / \mathrm{F}$ homozygous individuals. Although bands $\mathrm{B}, \mathrm{C}$, and $\mathrm{D}$ can distinguish reliably only $75 \%$ of the heterozygote carriers from $\mathrm{C} / \mathrm{F}$ homozygotes (Table 2), it may be possible to distinguish the remaining $25 \%$ by using an additional test. Either a standard sweat test $(20)$ could be performed (if screening is conducted before puberty to assure its accuracy) (27) or the suspected heterozygote simples could be screened for the presence of a $\beta$ globulin shown previously by isoelectric focusing to be absent in most $C / F$ homozygote sera (35). Both of these possibilities are presently being explored. Currently, little is known about bands $B, C$, and D: speculation regarding their function seems premature. since their possible role in the pathophysiology of $\mathrm{C} / \mathrm{F}$ must await further genetic studies involving the relatives and family members of the individual $\mathrm{C} / \mathrm{F}$ patient and heterozygous carrier for $\mathrm{C} / \mathrm{F}$.

The incidence of $\mathrm{C} / \mathrm{F}$ live births among Caucasians ranges from 1 in 1,500 to $I$ in $2,448(18,21)$. Thus, assuming that a single gene locus governs the inheritance of this disease, the $\mathrm{C} / \mathrm{F}$ heterozygote frequency has been estimated to be approximately 1 in $20(10,24)$. In the analysis of serum samples from 105 normal control subjects, we have found 9 who contained a $\mathrm{C} / \mathrm{F}$ factor protein band ( $T$ able 1). This frequency $(8.5 \%)$ does not differ significantly from the expected heterozygote frequency in the Caucasian population.

The results of our analysis of serum taken from patients suffering from a variety of other diseases, many with clinical symptoms similar to those seen in the $\mathrm{C} / \mathrm{F}$ patient $(27,29)$ (Table 3 ), indicate that the $\mathrm{C} / \mathrm{F}$ factor described in this and other reports $(32,33,35)$ appears to be specific for cystic fibrosis genotypes. With the exception of 4 patients with leukemia and 1 sibling of a $\mathrm{C} / \mathrm{F}$ patient, only 4 of 68 showed a $\mathrm{C} / \mathrm{F}$ factor band. This frequency of 4 of 68 normal patient control subjects agrees well with the expected frequency of heterozygote carriers for cystic fibrosis in the Caucasian population.

It is of interest that most of the patients with allergy, asthma, bronchitis, cirrhosis of the liver, diabetes mellitus, hypogammaglobulinemia, pancreatitis, recurrent pneumonia, and rheumatoid arthritis did not show a $\mathrm{C} / \mathrm{F}$ factor protein band (Table 3 ).

These results agree with those of Spock et al. (29) and Bowman et al. (8) who did not find a protein with $\mathrm{C} / \mathrm{F}$ factor activity (ciliary dyskinetic or ciliary static activity) in the sera obtained from these types of patients when patients were tested using either the rabbit tracheal (29) or oyster gill (8) ciliary bioassays.

On the other hand, our results (Table 3 ) do not agree totally with those of Conover et al. (14), who reported that sera from patients with agammaglobulinemia, bronchial asthma, chronic allergy, and lupus erythematosus produce a ciliary dyskinesiary effect similar to that observed for sera from $\mathrm{C} / \mathrm{F}$ patients and heterozygote carriers of the disease. The data of Conover et al. (14-16) implied that patients with these disease states produce a factor identical with the factor found in the $\mathrm{C} / \mathrm{F}$ patient. From our results (Table 3 ) it is clear that patients with these disease states do not harbor the same protein that we have found in both $\mathrm{C} / \mathrm{F}$ patients and heterozygous carriers for $\mathrm{C} / \mathrm{F}$.

The reason for a disagreement between our data and that of Conover et al. (14) may reside totally with the specificity of the assay systems involved. In the bioassays for $\mathrm{C} / \mathrm{F}$ factor $(4,8,13$, 29) a biologic activity of the $C / F$ factor is measured, namely, ciliary dyskinesis or stasis. Reports by various investigators indicate that this biologic activity attributed to $\mathrm{C} / \mathrm{F}$ factor is mimicked by other cationic molecules such as bradykinin (12) and polyamines $(6,9,16,23)$, and therefore, is not specific for the presence of $\mathrm{C} / \mathrm{F}$ factor in a given serum sample. Our isoelectric focusing assay, however, has considerably greater specificity in that it distinguishes the $\mathrm{C} / \mathrm{F}$ factor protein on the basis of its $\mathrm{pl}$. Other cationic proteins, regardless of their biologic activity in a ciliary bioassay, will not focus at the same $\mathrm{pl}$ as the $\mathrm{C} / \mathrm{F}$ factor unless their amino acid composition or total charge properties are identical with those of the $\mathrm{C} / \mathrm{F}$ factor protein.

The finding of a $\mathrm{C} / \mathrm{F}$ factor band in the serum of certain leukemic patients (Table 3 ) is of interest, although the reason for its presence in these patients is unclear. Of the different investigators utilizing either the rabbit tracheal or oyster gill ciliary bioassays for $\mathrm{C} / \mathrm{F}$ factor detection, only Spock et al. (29) has tested sera from leukemic patients. Two patients were tested, both were children with acute lymphocytic leukemia (ALL) and both were negative for $C / F$ factor (28). Of the two patients with acute 
Table 3. Frequency of cystic fibrosis factor in other disease states

\begin{tabular}{|c|c|c|c|}
\hline Disease & $\mathrm{IgG}, \mathrm{mg} / 100 \mathrm{ml}$ & Age, yr & $\begin{array}{l}\text { No. with cystic } \\
\text { fibrosis factor/ } \\
\text { No. tested }\end{array}$ \\
\hline Chronic allergy & $\begin{array}{l}945 \pm 357^{1} \\
550-1,700\end{array}$ & $\begin{array}{l}10.6 \pm 6 \\
4-20\end{array}$ & $1 / 8$ \\
\hline Bronchial asthma & $\begin{array}{l}908 \pm 428 \\
387-1,500\end{array}$ & $\begin{array}{l}10.8 \pm 5.2 \\
3.5-28\end{array}$ & $0 / 6$ \\
\hline Bronchitis & 804,721 & $5,7.6$ & $0 / 2$ \\
\hline Cirrhosis of the liver & $\begin{array}{l}1,060 \pm 383 \\
650-1,340\end{array}$ & $\begin{array}{l}37.4 \pm 20.3 \\
15-61\end{array}$ & $1 \pm / 5$ \\
\hline Diabetes mellitus & $946,527,611$ & $46,37,22$ & $0 / 3$ \\
\hline Hypokalemia with renal failure and hepatitis & 3.734 & 54 & $1 / 1$ \\
\hline Hypogammaglobulinemia & 100,300 & 2,45 & $0 / 2$ \\
\hline Kidney disease $^{2}$ & $\begin{array}{l}853 \pm 450 \\
446-1,700\end{array}$ & $\begin{array}{l}44 \pm 14.8 \\
21-54\end{array}$ & $0 / 9$ \\
\hline Lupus erythematosus & $900,1,030$ & 40,59 & $0 / 2$ \\
\hline Myocardial infarction & $927,1,200$ & 35,57 & $0 / 2$ \\
\hline Other circulatory ${ }^{3}$ disorders & $\begin{array}{l}1,069 \pm 320 \\
754-1,395\end{array}$ & $\begin{array}{l}65.6 \pm 12.6 \\
47-74\end{array}$ & $0 / 5$ \\
\hline Pancreatitis & 1,059 & 36 & $0 / 1$ \\
\hline Recurrent pneumonia & $1,400,450,900$ & $52,3.5,8$ & $0 / 3$ \\
\hline Rheumatoid arthritis & $1,400,1,100$ & 52,45 & $0 / 2$ \\
\hline $\begin{array}{l}\text { Cancer } \\
\text { leukemia }^{4}\end{array}$ & $\begin{array}{l}1,261 \pm 836 \\
254-2,498\end{array}$ & $\begin{array}{l}45 \pm 28 \\
6-74\end{array}$ & $3+, 1 \pm / 5$ \\
\hline Bladder cancer & 527 & 56 & $1 / 1$ \\
\hline Multiple myeloma & $6,000,8,121$ & 40,65 & $0 / 2$ \\
\hline Pancreatic cancer & $1,778,809,614,979$ & $51,55,58,40$ & $1 / 4$ \\
\hline Lung cancer & $861,1,400$ & 40,59 & $0 / 2$ \\
\hline Hepatoma & 817 & 22 & $0 / 1$ \\
\hline Porphyria cutanea tarda & 1,206 & 60 & $0 / 1$ \\
\hline Cancer of the thalamus & 529 & 49 & $0 / 1$ \\
\hline Metastatic cancer of the bone & 1,266 & 50 & $0 / 1$ \\
\hline
\end{tabular}

Total with cystic fibrosis factor/total studied

$7+, 2 \pm / 69$

${ }^{1}$ Mean $\pm \mathrm{SD}$, and range listed when number studied equals 5 or more, otherwise, all values are listed.

${ }^{2}$ Included: one nephrasthenia, one acute tubular nephrosis, one nephrocystitis, five renal transplants, one acute glomerulonephritis.

${ }^{3}$ Included: two pulmonary embolism, one hypertensive arteriosclerosis, two heart surgeries, one mitral valve replacement, one aortic valve replacement

${ }^{4} 3+$ : two acute granulocytic leukemia, one chronic manocytic leukemia; $1 \pm$ : acute lymphocytic leukemia; 1 -: acute lymphocytic leukemia.

lymphocytic leukemia we have studied, one was negative and one was \pm for the presence of a $C / F$ factor band. Two patients with acute granulocytic leukemia and one with chronic monocytic leukemia, however, were positive for a $\mathrm{C} / \mathrm{F}$ factor band

Further study of sera from leukemia patients is indicated to ascertain whether these preliminary findings are by chance alone or whether they may indicate that an abnormality in protein production by granulocytes or monocytes may be implicated as a possible reason for $\mathrm{C} / \mathrm{F}$ factor production or accumulation in individuals homozygous and heterozygous for the $\mathrm{C} / \mathrm{F}$ gene.

\section{SUMMARY}

The methodology of a biophysical assay for the detection of individuals homozygous or heterozygous for cystic fibrosis $(\mathrm{C} / \mathrm{F})$ has been described in detail. The assay employs isoelectric focusing in thin layer polyacrylamide gels to analyze whole serum samples for the presence of a $\mathrm{C} / \mathrm{F}$ factor protein and for deletions in a group of proteins called proteins $\mathrm{B}, \mathrm{C}$, and $\mathrm{D}$. Individuals homozygous or heterozygous for $\mathrm{C} / \mathrm{F}$ are distinguished from normal unaffected individuals on the basis of the presence of a $\mathrm{C} / \mathrm{F}$ factor protein band. Heterozygous carriers for $\mathrm{C} / \mathrm{F}$ are distinguished from $\mathrm{C} / \mathrm{F}$ homozygotes $75 \%$ of the time, on the basis of a deletion in either protein B, C, and D. The assay is rapid and standardized in that: $(l)$ each sample is analyzed using a volume of whole serum which contains $300 \mu \mathrm{g} \mathrm{IgG,} \mathrm{(2)} \mathrm{multiple} \mathrm{samples} \mathrm{can}$ be analyzed under nearly identical experimental conditions, and (3) all proteins of diagnostic value occur on the same gel (a pH 5-10 gradient), thus eliminating the need to run more than one type of gel to analyze a group of samples.

The results of analyzing $65 \mathrm{C} / \mathrm{F}$ patients, 61 heterozygous carriers for $\mathrm{C} / \mathrm{F}$, and 105 normal control subjects indicated that there was no obvious correlation between either age or sex and the presence of $\mathrm{C} / \mathrm{F}$ factor or deletions in bands $\mathrm{B}, \mathrm{C}$, or $\mathrm{D}$ in the individual $\mathrm{C} / \mathrm{F}$ patient, heterozygous carrier for $\mathrm{C} / \mathrm{F}$, or normal control subject. There was also no obvious correlation between the severity of the disease in the individual $C / F$ patient and the absolute presence or absence of the $\mathrm{C} / \mathrm{F}$ factor protein described in this study. The results of analyzing serum samples from 68 individuals with a variety of other diseases, many with clinical symptoms resembling those seen in the patient with cystic fibrosis, indicated that the $\mathrm{C} / \mathrm{F}$ factor protein described in this study appears to be diagnostic for $\mathrm{C} / \mathrm{F}$ genotypes.

\section{REFERENCES AND NOTES}

1. Barnett, D. R., Kurosky, A., Bowman, B. H., and Barranco, S. C.: Loss of ciliary inhibitory effect of the cystic fibrosis factor following proteolytic digestion and heat denaturation. Tex. Rep. Biol. Med., 31: 697 (1973).

2. Barnett, D. R., Kurosky, A., Bowman, B. H., Hutchison, H. T., Schmoyer, I. 
and Carson, S. D.: Cystic fibrosis: Molecular weight estimation of the ciliary inhibitor. Tex. Rep. Biol. Med., 3l: 703 (1973).

3. Beratis, N.G., Conover, J. H., Conod, E. J., Bonforte, R. J., and Hirschhorn, K.: Studies on ciliary dyskinesia factor in cystic fibrosis. IHI. Skin fibroblasts and cultured amniotic fluid cells. Pediat. Res., 7: 958 (1973)

4. Besley, G. T. Patrick, A. D.. and Norman, A. P.: Inhibition of the motility of gill cilia of Dreissensia by plasma of cystic fibrosis patients and their parents. J. Med. Genet., 6: 228 (1969).

5. Bowman, B. H.: Introduction: Progress in research toward identifying the basic defect in cystic fibrosis. Tex. Rep. Biol. Med., 31: 611 (1973).

6. Bowman, B. H., Barnett, D. R., and Matalon, R.: Detection and characterization of the cystic fibrosis ciliary inhibitor. In: J. A. Mangos and R. C. Talamo:

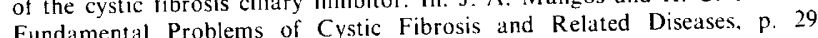
Fundamental Problems of Cystic Fibrosis and Related Diseas

7. Bowman, B. H. Barnett, D. R. Matalon, R., Danes, B. S., and Bearn. A. G. Isolation of the cystic fibrosis ciliary inhibitor from fibroblatst media. Proc. Nat. Acad. Sci. U.S.A., 70: 548, (1973).

8. Bowman, B. H., Lockhart. L. H., and McCoombs, M. L.: Oyster ciliary inhibition by cystic fibrosis factor. Science, 164: 235 (1969).

9. Bowman, B. H., McCombs, M. L., and Lockhart, L. H. Cystic fibrosis: Characterization of the inhibitor to ciliary action in oyster gills. Science, 167. $871(1970)$

10. Conneally, P. M., Merritt, A. D., and Yu, P.: Cystic fibrosis: Population genetics Tex. Rep. Biol. Med., 31: 639 (1973)

11. Conover, J. H., Beratis, N. G., Conod, E. J., Ainbender, E., and Hirschhorn, K.: Studies on ciliary dyskinesia factor in cystic fibrosis. II. Short term leukocyte Studies on ciliary dysm lymphoid lines. Pediat. Res., 7: 224 (1973).

12. Conover. J. H., Beratis, N. G., Conod, E. J., Hathaway, P.. and Hirschhorn, K.: Ciliary dyskinesia factor produced in tissue culture from cystic fibrosis. Clin. Res.. 21: 531 (1973).

13. Conover, J. T., Bonforte. R. J., Hathaway, P., Paciuc, S., Conod, E. J., Hirschhorn, K., and Kobel, F. B.: Studies on ciliary dyskinesia fact or in cystic fibrosis. I. Bioassay and heterozygote detection in serum. Pediat. Res., 7: 220 (1973).

14. Conover, J. T. Conod, E. J., and Hirschhorn, K.: Ciliary dyskinesia factor in immunological and pulmonary disease. Lancet, $i$ : 1194 (1973).

15. Conover, J. H., Conod, E. J., and Hirschhorn, K.: Complement components in cystic fibrosis. Lancet, ii: 1501 (1973).

16. Conover, J. T., Conod, E. J., and Hirschhorn, K.: Studies on ciliary dyskinesia factor in cystic fibrosis. IV. Its possible identification as anaphylatoxin (C3a)-IgG complex. Life Sci., 14: 253 (1974).

17. Danes, B. S. Litwin. S. D., Hutteroth, T. H., Cleve, H., and Bearn. A. G.: Characterization of cystic fibrosis factor and its interaction with human immunoglobulin. J. Exp. Med., 137: 1538 (1973)

18. Danks, D. M Allan, J., and Anderson, C. M.: A genetic study of fibrocystic disease of the pancreas. Ann. Human Genet., 28: 323 (1965)

19. Fahey, J. L., and McKelvey, E. M.: Quantitative determination of serum immunoglobulins in antibody-agar plates. J. Immunol., 94: 84 (1965).

20. Gibson, L. E., and Cooke, R. E.: A test for concentration of electrolytes in sweat in cystic fibrosis of the pancreas utilizing pilocarpine by iontophoresis. Pediatrics, 23: 545 (1959)

21. Lobeck, C. C.: Cystic fibrosis of the pancreas. In: J. B. Stanbury, J. B. Wyngaarden, and D. S. Fredrickson: The Metabolic Basis of Inherited Disease, Ed. 3 (McGraw-Hill, New York, 1972).

22. quantitation of antigens by single radial immunodiffusion. Immunochemistry, 2: 235 (1965).

23. Mangos, J. A., and McSherry, N. R.: Studies on the mechanism of inhibition of sodium transport in cystic fibrosis of the pancreas. Pediat. Res., 2: 378 (1968)

Copyright (c) 1975 International Pediatric Research Foundation, Inc.
24. McCombs, M. L.: Research in cystic fibrosis: A review. Tex. Rep. Biol. Med., 31: $615(1973)$

5. McCombs, M. L.. and Bowman. B. H.: Rivinol treatment of cystic fibrosis serum: Effect of supernatant upon ciliary action. Clin. Genet., I: 171 (1970)

26. Schmoyer I. R. Fischer, J. F., and Brooks, S. P.: Fractionation of oyster cilia inhibitor from cystic fibrosis heterozygote serum. Biochem. Biophys. Res. Commun., 46: 1923 (1972)

27. Schwachman, H.: Cystic fibrosis. In: E. L. Kendig. Disorders of the Respiratory Tract in Children, p. 541 (W. B. Saunders Company, Philadelphia, 1967).

28. Spock, A.: Personal communication.

29. Spock A. Heick, H M C Cress, H. and Logan, W. S.: Abnormal serum factor in patients with cystic fibrosis of the pancreas. Pediat. Res., I: 173 (1967).

30. Williamson, A. R.: Isoelectric focusing of immunoglobulins. In: D. M. Weir: Handbook of Experimental Immunology. Ed. 2, Chap. 8, p. 1 (Blackwell Scientific Publications, Oxford, 1973).

31. Wilson, G. B.: Unpublished observations.

32. Wilson, G. B.: Studies on the cystic fibrosis serum factor and on the nature of the ciliary beat of Colpidium strianum. Ph.D. Thesi

33. Wilson, G. B., and Fudenberg. H. H.: Characterization of the cystic fibrosis factor shown by isoelectric focusing (in preparation).

34. Wilson, G. B., and Jahn, T. L.: Decreased rate of cytolysis of Colpidium striatum by cystic fibrosis serum. 1. Bioassay and evidence for the possible involvement of a C/F factor-IgG complex. Life Sci.. 51: 551 (1974).

35. Wilson, G. B., Jahn, T. L., and Fonseca, J. R.: Demonstration of serum protein differences in cystic fibrosis by isoelectric focusing in thin-layer polyacrylamide gels. Clin. Chim. Acta, 49: 79 (1973).

36. LKB Produkter A. B., Stockholm, Brooma, Sweden. $\mathrm{pH} \mathrm{5-8.8-9.5,} \mathrm{and} \mathrm{7.9}$ Ampholine carrier ampholytes are supplied as $40 \%(\mathrm{w} / \mathrm{v})$ solutions; $\mathrm{pH} 9-11$ Ampholine carrier ampholytes are supplied as a $20 \%(\mathrm{w} / \mathrm{v})$ solution.

Ampholine carrier ampholytes are supplied and $N, N^{1}$-methlenebisacrylamide were both electrophoresis grade and were obtained from Eastman Organic Chemicals, Rochester, N. Y.

38. $N$ N $N^{1} N^{1}$-Tetramethylethylenediamine. Eastman Organic Chemicals, Rochester, N. Y.

39. $\% \mathrm{~T}=$ grams of acrylamide + grams of bisacrylamide $/ 100 \mathrm{ml}$ of solution: $\% \mathrm{C}=$ 100 times grams of bisacrylamide/ $100 \mathrm{ml}$ solution $/ \mathrm{T}$. Nomenclature according to Vesterberg. O., and Nise, G.: Urinary proteins studied by use of isoelectric focusing. 1. Tubular malfunction in association with exposure to cadmium. Clin. Chem., 19: 1179 (1973).

40. The $\mathrm{lgG}$ level in serum is measured as milligrams per $100 \mathrm{ml}$ or milligrams per millititer by single radial immunodiffusion $(19,22)$. This value is converted to micrograms per microliter and divided into 300 to give number of microliters micrograms per microliter and divide focusing. For example: $1,000 \mathrm{mg} / 100 \mathrm{ml}$ $=10 \mu \mathrm{g} / \mu \mathrm{l} ; 300 \mu \mathrm{g} / 10 \mu \mathrm{g} / \mu \mathrm{l}=30 \mu \mathrm{l}$ serum.

41. Tiffen photar orange filters, series 7 or the equivalent. Tiffen Optical Co., Long Island, N. Y

42. The authors gratefully acknowledge the help of Richard Dooley, M.D., Birt Harvey, M.D. Michael McCombs, Ph.D.. Alan Osher, M.D., and Louise Yeazell, M.D in obtaining the blood samples used in this investigation.

43. Dr. G. B. Wilson is a Postdoctoral Research Fellow of the National Cystic Fibrosis Research Foundation (N.C.F.R.F.).

44. The research was supported in part by United States Public Health Service Grants AM 14388 and HD-05894, by a grant from the NCFRF, and by National Institutes of Health Grant Al-09145.

45. Requests for reprints should be addressed to: G. B. Wilson, Ph.D., Section of Immunology (475 HSW), Department of Medicine, University of California, San Francisco, California 94143 (USA)

46. Accepted for publication April 8, 1975. 